ELORE (ISSN 1456-3010), vol. 19 - 2/2012.

Julkaisija: Suomen Kansantietouden Tutkijain Seura ry.

[http://www.elore.fi/arkisto/2_12/pk_stranden-backa_hytonen.pdf]

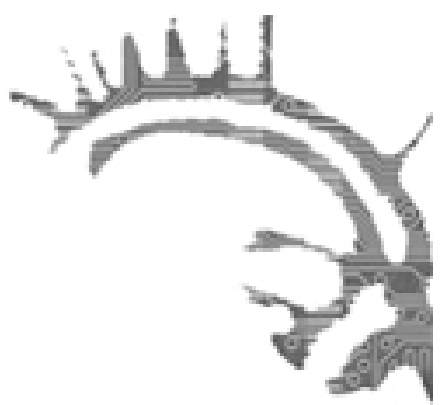

\title{
LEDARE
}

\section{EMINENTA TEXTER}

\section{$\underline{\text { Sofie Strandén-Backa och Elina Hytönen }}$}

Höstens nummer av Elore har inget givet tema, men ändå är det förvånande många texter som kretsar kring frågeställningar om forskningsetik och forskningshistoria. Den tyngsta forskningshistoriska delen återfinns självfallet i Eminentia-föreläsningarna. Suomen kansantietouden tutkijain seura (SKTS) - Sällskapet för forskare i folkloristik i Finland - firade sitt 75-årsjubileum i maj genom att anordna en föreläsningsdag i anslutning till sällskapets årliga forskarskola. Föreläsningsdagen benämndes "Eminentia” och som föreläsare inbjöds eminenta forskare som ombads reflektera över centrala frågeställningar i folkloristiken utgående från deras egen långa erfarenhet som forskare. Det var många som kom för att åhöra föredragen. Elore har äran att erbjuda tre av dessa föredrag i detta nummer: professorerna Satu Apo, Aili Nenola och Seppo Knuuttila har alla gett sina föredrag i skriftlig form till oss. Sällskapets nuvarande ordförande, Sinikka Vakimo, bidrar också med sitt inledningsföredrag, där hon förklarar hur sällskapet vuxit fram genom åren. Under Eminentiadagen sammanfattade professor Pekka Hakamies föreläsningarna, och i det här numret skriver han om sina reflektioner från dem i sin kolumn.

Satu Apos föredrag, vars titel i svensk översättning lyder "Sagogenren, ett slagfält mellan litteraturvetenskap och folkloristik" handlar om en vetenskaplig dispyt om folksagornas ursprung och ålder. Inom folkloristiken råder en allmän uppfattning om att det vi kallar för folksagor har en obruten, muntlig tradition sedan tusentals år tillbaka. Litteraturvetaren Ruth Bottigheimer har ifrågasatt denna föreställning, och fått mothugg i bland annat ett helt nummer av Journal of American Folklore. I sitt föredrag redogör Apo för argumenten för och emot, och delger oss läsare också sin egen förhållning. Enligt henne måste man i dag räkna med den tryckta litteraturens påverkan när 
man diskuterar sagors och sägners historia, och hon menar att vi som folklorister måste ompröva hela den sagoforskning som hittills bedrivits.

Aili Nenola diskuterade kvinnoforskningens framväxt inom den finska folkloristiken i sitt föredrag "Kvinnoberättelsen". Hon visade på vikten av att ställa sig frågor som varför historia och forskningshistoria är så mansdominerade, och varför så mycket forskning bedrivits ur ett mansperspektiv. Om kvinnor över huvud taget blivit synliggjorda i dessa sammanhang har de enligt henne getts en roll som påminner om statistens. En förklaring hon ger är att kvinnorna innan emancipationen var utestängda från offentlig verksamhet och offentlig debatt. Nenola ger efter detta en kort historisk överblick över kvinnoemancipationen i Finland - från avskaffandet av förmyndarskap för kvinnor på 1864 till abortlagstiftningen på 1970-talet.

Seppo Knuuttilas föredrag "Från folkloristikens kognitiva hierarkier till begreppslig relativism" diskuterar hur olika man som vetenskapare förhållit sig till sitt studiematerial genom tiderna. När ett tidigare förhållningssätt innebar att man försökte ställa sig utanför materialet, kanske till och med påvisa hur "fel" ens studieobjekt tänkte, omformades uppfattningen i synnerhet under 1980-talet till att problematisera hur materialet tillkommit och utvärdera forskningsresultatens hållbarhet. Det här kan ses som en följd av ett tidigare textcentrerat förhållningssätt till ett senare antropologiskt där forskaren ses som en aktiv del av forskningsmaterialet och som något som därmed också måste studeras.

Knuuttila delger oss exempel från riktigt nya doktorsavhandlingar, däribland Pasi Enges, vars lectio vi också får läsa i detta nummer. Eftersom Enges lectio både omnämndes av Knuuttila och ger en forskningshistorisk överblick av Åboskolan placeras den i nära anslutning till Eminentia-texterna. Enges placerar in sin forskning om samisk folktro på ett mycket förtjänstfullt sätt i ett vidare forskningshistoriskt sammanhang, och diskuterar de olika paradigm som varit rådande under mer än ett sekel. Han menar själv att hans egen avhandling är den sista med direkt koppling till Åboskolan och ett arv efter Lauri Honko. Samtidigt innebär hans forskning en nödvändig vidareutveckling av de utgångspunkter som man hade när materialet som han använder sig av samlades in på 1960-talet. Andra frågor ställs idag, och en viktig del av dem handlar om att problematisera tillkomsten av materialet.

Knuuttila betonar vikten av att förstå ett fenomen utgående från dess referensramar, och att inte döma ut något för att det inte stämmer överens med forskarens egna referensramar. Den här frågeställningen återfinns i tre av de artiklar som finns i det här numret. Pia Olsson skriver i sin artikel, vars rubrik i översättning lyder "En annorlunda etnografi? Utvecklingsstörda ungdomar i etnografiskt fältarbete" om problemet att förstå dem man studerar och acceptera deras argumentation och världsbild samtidigt som man ska hålla kvar sitt vetenskapliga tänkesätt. Sven-Erik Klinkmanns artikel "Forskning som förstärker stereotypisering" är en kritisk granskning av sociologen Riie Heikkiläs avhandling om finlandssvenskars smak. Klinkmann lyfter fram brister bland annat i självreflexivitet och självpositionering, vilket medför frapperande grova forskningsetiska övertramp. Camilla Kronqvist gör å sin sida en forskningsetisk studie av talet om känslor i intervjubaserad forskning. Kronqvist är filosof, och skriver sin artikel "Känsla och självkännedom" utgående från ett filosofiskt resonemang om känslor. Merja Leppälahti ger prov på folktroforskning i kombination med litteratur. I sin artikel, vars rubrik i översättning 
lyder: "Levande döda, shapeshifters och andra underliga varelser" skriver hon om hur folktradition blir fantasy. Vi tackar alla våra många och anonyma refereegranskare för det viktiga arbetet de utfört när de läst artiklarna, granskat det vetenskapliga innehållet, kommenterat och gjort förbättringsförslag.

Artiklarna presenteras medvetet inte längre än så här, eftersom vi från och med detta nummer har gjort översättningar av lite längre artikelabstract från finska till svenska och från svenska till finska. Arbetet görs uttryckligen för att främja forskningssamarbetet $\mathrm{i}$ landet och för att föra ut den finskspråkiga forskningen till det skandinaviska språkområdet. Vi tror att en sammanfattning på en sida ger en tillräckligt god överblick av artikelns innehåll för att ge vidare impulser till att läsa artikeln på ett språk som kan kännas ovant och svårtillgängligt. Kanske ett översatt längre abstract kan leda till kontakter för närmare diskussioner om dittills okända näraliggande vetenskapsämnen.

En annan nyhet som gäller från och med detta nummer är att vi numera har två kategorier av artiklar: Vi skiljer enbart mellan artiklar och översikter. Den svårdefinierade kategorin översiktsartikel utgår. I detta nummer har vi tre teoretiska översikter: Liisa Granbom-Herranen skriver om olika perioder i den finska ordspråksforskningen. Anna Rajavuori lyfter fram det muntliga som föremål för historievetenskaplig forskning. Sofie Strandén-Backa ger en kort översikt av identitetsforskning för att ge en bakgrund till den italienska filosofen Adriana Cavareros begrepp identitetsbegär. Den fjärde översikten ger Timo Leisiö i form av en inblick i två skogsfinska maträtter "mutti" och "pepu". Vi vill här rikta ett särskilt tack till Pekka Hakamies och Sven-Erik Klinkmann som läst och kommenterat Granbom-Herranens respektive Strandén-Backas forskningsöversikter. Det är en rikedom att ha kunniga forskare att fråga när expertis behövs.

Utöver föredrag, artiklar och översikter har vi också två intressanta konferensrapporter och som vanligt riktigt många bokrecensioner. Vi tar gärna emot flera rapporter från konferenser och seminarier. Vad har ni tagit del av i Finland och ute i världen som kunde intressera också andra? Eller - har ni något på hjärtat som ni vill föra fram som direkt berör kulturvetenskapligt inriktade forskare? I det här numret är det författare, docent och förläggare Helena Saarikoski som delar med sig av sina erfarenheter i ett viktigt debattinlägg. Hon höll ett anförande på SKTS:s vårskola i maj om den finskspråkiga vetenskapliga litteraturens öde, och nu får vi läsa om hennes tankar om detta ämne. Saarikoski skriver om att skriva olika typ av vetenskaplig litteratur och hur sådan litteratur tas emot av förlag, läsare och granskare. Hon diskuterar dilemmat mellan att ge ut formellt strikt vetenskapliga böcker som inte köps och läses av så många men som ger streck i rätt kolumn när universitetens effektivitet bedöms, och andra typer av vetenskaplig litteratur, med lika högtstående vetenskapligt innehåll, men med en form som inte följer föreställningar om "Riktig Vetenskap" och som därmed riskerar att degraderas och inte räknas exempelvis när man söker en akademisk tjänst. Det är många tänkvärda erfarenheter som Saarikoski delar med sig av i det här inlägget, och det finns skäl för alla oss som skriver vetenskap som intresserar allmänheten att fundera på det hon skriver.

Vi har från och med det här numret gått in för att efterlysa abstract för artiklar och översikter. Efterlysningen lockade många intresserade skribenter, och vi valde ut de abstract som vi ansåg skulle mest betjäna en kulturvetenskapligt intresserad läsekrets, och resultatet syns nu i detta nummer. Våra stadigvarande datum för abstractinlämning är den 
2.5 för numret som utkommer på hösten, och 2.9 för det temanummer som utkommer på våren. Nästa nummer är redan under arbete, och har temat "Djur". Vi har två gästande artikelredaktörer med djur i ett kulturvetenskapligt hänseende som specialområde: Taija Kaarlenkaski och Sari Ung-Lanki. Utgående från de abstract vi fått in kan vi förvänta oss artiklar som handlar om hundar, hästar, åsnor, papegojor och nyckelpigor.

Till sist vill vi tacka alla som varit involverade i arbetet med det här numret, ett ovanligt digert sådant. Förutom de som redan nämnts vill vi tacka också alla skribenter som idogt fortsatt arbeta och förbättra sina texter i enlighet med såväl redaktörernas som granskarnas kommentarer. Tack också alla Elores redaktörer för det arbete ni gjort för att texterna i det här numret har fått sin slutliga utformning. Vår nya layoutare Johanna Björkholm har gjort ett utmärkt arbete och har hela tiden varit just så flexibel med tiden som ett för alla pressat tidsschema har tillåtit. Vi önskar alla goda och hållbara läsestunder! 